\title{
Muscle strength training program in nonagenarians - a randomized controlled trial
}

\author{
(D) Iosé Maria Cancela Carral \\ DAdriana López Rodríguez ${ }^{1}$ \\ (D) rimia Mollinedo Cardalda ${ }^{1}$ \\ (D) José Pedro Arieiro Gonçalves Bezerra²
}

1. HealthyFit Research group, Department of Special Didactics, University of Vigo, E-36005, Faculty of Education Science and Sports, Pontevedra, Spain 2. School of Sports and Leisure, Polytechnic Institute of Viana do Castelo, Portugal

http://dx.doi.org/10.1590/1806-9282.65.6.851

\section{SUMMARY}

OBJECTIVES: The study aims to improve the functional capacity and quality of life ( $Q O L)$ of nonagenarian women by implementing an individualized muscle strength training program in a geriatric residential care home.

STUDY DESIGN: A randomized controlled trial

METHODS: Twenty-six elderly women were randomized into a control group (CG) and an intervention group (SG). The SG carried out a strength program with TheraBands ${ }^{\circledR}$ for 12 weeks, with two weekly sessions. The assessment tools that we used pre-and post-intervention were the Barthel index of daily living activities, the five times sit-to-stand test (FTSTS) and timed up and go (TUG) test with wiva ${ }^{\circledR}$ sensors.

RESULTS: The SG maintained the Barthel index scores for activities of daily living and improved in the FTSTS; the CG showed a significant decrease on both tests. The dynamic balance test showed significant differences between groups for the variables sit to stand, peak angular velocity, anterior-posterior range, turning, stand to sit, total time, and speed.

CONCLUSIONS: Individualized muscle strength training programs may help promote healthy lifestyles in such populations by maintaining autonomy, improving function and balance.

KEYWORDS: Exercise Therapy. Exercise. Frailty. Postural Balance. Quality of Life. Aged.

\section{INTRODUCTION}

The increase in life expectancy together with the decrease in birth rates in industrialized countries means that health care systems and public health policymakers need to focus their attention towards promoting healthy lifestyles at the highest sector of the population pyramid'. Frailty syndrome is an age-associated condition that is characterized by decreases in the functional reserve and resistance to stressors, related to different physiological systems. This syndrome is strongly associated with sarcopenia and puts older individuals at special risk for disability, hospitalization, and death induced by falls ${ }^{2-4}$. Along with sarcopenia, skeletal muscle fat infiltration, which is assessed through mus-

DATE OF SUBMISSION: 31-Mar-2019

DATE OF ACCEPTANCE: 19-Apr-2019

CORRESPONDING AUTHOR: José M. Cancela Carral

Campus A Xunqueria s/n E-36005, Faculty of Education Science and Sports, Pontevedra, Spain

Tel: 0034 986801799, Fax: 0034986801701

E-mail: chemacc@uvigo.es 
cle tissue attenuation, it is associated with an increased risk of reduced mobility, in both older men and women ${ }^{5}$. Frailty also increases with age and is associated with disease and disability and can be identified by the presence of three or more of the following criteria: unintentional weight loss, weakness, slow walking speed, low physical activity, and exhaustion ${ }^{6}$.

Several studies have reported that physical activity intervention programs, aiming to develop physical capacities in aged people, have positive effects on function and autonomy ${ }^{1,7}$. This is particularly evident in nonagenarians in whom the decrease in physical activity results in loss of function ${ }^{8}$.

The present study is an attempt to improve functional capacity and quality of life (QOL) of nonagenarians by implementing an individualized strength training program in a geriatric residential care home.

\section{METHODS}

This is a randomized controlled pilot study with two groups of participants. One group was submitted to an intervention program, including muscle strength training with TheraBands ${ }^{\circledR}$ (SG); the second group, control group (CG), was asked to maintain their daily routines. Two assessments were defined, at the week before intervention (week 0 ) and the last week of the intervention (week 12).

\section{PARTICIPANTS}

Participants in this study were recruited through a collaboration agreement between the University of Vigo (Spain) and "Fundación San Rosendo", a company for the management of residential care homes for older adults. Individuals with the following criteria were included: (a) frail older females ${ }^{6}$, (b) cognition mini-exam $<23^{9}$, (c) aged over 85 years, (d) able to stand and walk for at least 30 meters without shortness of breath, (e) able to walk safely and independently without aid, (f) resident in a geriatric longterm care home.

\section{PROCEDURES}

All the participants and their families were previously informed about the characteristics of the research protocol. The study was approved by the clinical research ethics committee of the University of
Vigo (CE 14-1009-17), and all participants gave their informed consent.

\section{INTERVENTION}

Participants were randomly assigned to either the SG or CG. The SG participated in a 12-week training program which consisted of two 60-minute sessions per week, focused on improving lower limbs muscle strength by using TheraBands ${ }^{\circledR}$. The training program included 10 exercises focused on lower limb muscle strength (plantar and dorsiflexors; knee flexors and extensors; hips flexors, extensors, abductors, adductors, and rotation), in which 2 to 4 exercises were implemented per session (for details see Table 1).

The CG was asked to maintain daily routines (handcraft, reading, and cognitive stimulation) with no systematic physical activity.

Both programs were developed by physiotherapists and physical activity professionals with more than 5 years of experience in therapeutic work with older adults. The evaluation was developed by the HealthyFit research group (University of Vigo), healthcare professionals, and experts in the evaluation of the physical condition of older adults.

\section{ASSESSMENTS}

Participants were assessed the week before the training program (week 0) and on the last week of the intervention (week 12). The testing protocol was defined as the anthropometric measures, functional assessment, and dynamic balance assessment.

Anthropometric measures included; height (stadiometer handac) which was assessed in $\mathrm{cm}$ with 1.0 $\mathrm{mm}$ precision; weight (Tanita TBF300), assessed in $\mathrm{kg}$ with $0.1 \mathrm{~kg}$ precision; and BMI, calculated according to the following formula- weight $/ \mathrm{height}^{2}\left(\mathrm{~kg} / \mathrm{m}^{2}\right)$. Participants were assessed while barefoot and lightly clothed.

The functional assessment included; the Barthel index of daily living activities and the five times sit-to-stand test. The Barthel index of daily living activities included a 10-item questionnaire aiming to assess individual autonomy concerning daily life activities. Each participant's functional capacity, according to the Barthel index, is referenced in order to better prescribe the intervention program. The score range goes from 0 to 100 , assuming the higher the 
TABLE 1: MUSCLE STRENGTH TRAINING PROGRAM DESCRIPTION

\begin{tabular}{|c|c|c|c|c|c|c|c|c|c|c|c|c|}
\hline Week & \multicolumn{2}{|l|}{$1-2$} & \multicolumn{2}{|l|}{$3-5$} & \multicolumn{2}{|l|}{$6-7$} & \multicolumn{2}{|l|}{$8-10$} & \multicolumn{2}{|l|}{11} & \multicolumn{2}{|l|}{12} \\
\hline Session & Type A & Type B & Type C & Type D & Type E & Type F & Type E & Type F & Type E & Type F & Type E & Type F \\
\hline $\begin{array}{l}\text { Method- } \\
\text { ology }\end{array}$ & \multicolumn{2}{|c|}{$\begin{array}{l}2 \text { exercises } \\
10 \text { reps } x 2 \text { series } x \\
\text { exercise } \\
\text { Pause: } 40 \text { s/10reps; } \\
60 \text { s/exercise }\end{array}$} & \multicolumn{2}{|c|}{$\begin{array}{l}2+1 \text { exercises } \\
15 \text { reps } x 3 \text { series } x \\
\text { exercise } \\
\text { Pause: } 40 \text { s/15reps; } \\
60 \text { s/exercise }\end{array}$} & \multicolumn{2}{|c|}{$\begin{array}{l}3+1 \text { exercises } \\
15 \text { reps } x 3 \text { series } x \\
\text { exercise } \\
\text { Pause: } 40 \text { s/15reps; } \\
\text { 60s/exercise }\end{array}$} & \multicolumn{2}{|c|}{$\begin{array}{l}3+1 \text { exercises } \\
15 \text { reps } \times 3 \text { series } \times \text { exercise } \\
\text { Pause: } 35 \text { s/15reps; } 55 \text { s/exercise }\end{array}$} & \multicolumn{2}{|c|}{$\begin{array}{l}3+1 \text { exercises } \\
15 \text { reps } x 3 \text { series } x \\
\text { exercise } \\
\text { Pause: } 30 \text { s/15reps; } \\
\text { 45s/exercise }\end{array}$} & \multicolumn{2}{|c|}{$\begin{array}{l}3+1 \text { exercises } \\
15 \text { reps } \times 3 \text { series } x \\
\text { exercise } \\
\text { Pause: Os/exercise }\end{array}$} \\
\hline Warm-up & \multicolumn{12}{|c|}{ Foot Abduction and adduction./ Heel movements. /Circumduction with the foot. / Plantar flexors with ankle extension. } \\
\hline $\begin{array}{l}\text { Principal } \\
\text { Phase }\end{array}$ & $\begin{array}{l}\text { Ankle } \\
\text { exten- } \\
\text { sion. } \\
\text { Ankle } \\
\text { abduc- } \\
\text { tion and } \\
\text { adduc- } \\
\text { tion. } \\
\text { with hip } \\
\text { rotation }\end{array}$ & $\begin{array}{l}\text { Knee } \\
\text { flexion/ } \\
\text { exten- } \\
\text { sion. } \\
\text { Hip } \\
\text { flexion }\end{array}$ & $\begin{array}{l}\text { Knee } \\
\text { flexion/ } \\
\text { exten- } \\
\text { sion } \\
\text { Hip } \\
\text { flexion } \\
\text { Hip flex- } \\
\text { ion and } \\
\text { abduc- } \\
\text { tion }\end{array}$ & $\begin{array}{l}\text { Ankle } \\
\text { exten- } \\
\text { sion. } \\
\\
\text { Ankle } \\
\text { abduc- } \\
\text { tion and } \\
\text { adduc- } \\
\text { tion. } \\
\text { with hip } \\
\text { rotation } \\
\text { Hip flex- } \\
\text { ion and } \\
\text { abduc- } \\
\text { tion }\end{array}$ & $\begin{array}{l}\text { Knee } \\
\text { flexion/ } \\
\text { exten- } \\
\text { sion } \\
\text { Hip } \\
\text { flexion } \\
\text { Hip flex- } \\
\text { ion and } \\
\text { abduc- } \\
\text { tion } \\
\text { Plantar } \\
\text { flexion }\end{array}$ & $\begin{array}{l}\text { Ankle } \\
\text { exten- } \\
\text { sion. } \\
\text { Ankle } \\
\text { abduc- } \\
\text { tion and } \\
\text { adduc- } \\
\text { tion. } \\
\text { with hip } \\
\text { rotation } \\
\text { Knee } \\
\text { flexion } \\
\text { Hip ab- } \\
\text { duction }\end{array}$ & $\begin{array}{l}\text { Knee } \\
\text { flexion/ } \\
\text { exten- } \\
\text { sion } \\
\text { Hip } \\
\text { flexion } \\
\text { Hip flex- } \\
\text { ion and } \\
\text { abduc- } \\
\text { tion } \\
\text { Plantar } \\
\text { flexion }\end{array}$ & $\begin{array}{l}\text { Ankle extension. } \\
\text { Ankle abduction and } \\
\text { adduction. } \\
\text { with hip rotation } \\
\text { Knee flexion } \\
\text { Hip abduction }\end{array}$ & $\begin{array}{l}\text { Knee } \\
\text { flexion/ } \\
\text { exten- } \\
\text { sion } \\
\text { Hip } \\
\text { flexion } \\
\text { Hip flex- } \\
\text { ion and } \\
\text { abduc- } \\
\text { tion } \\
\text { Plantar } \\
\text { flexion }\end{array}$ & $\begin{array}{l}\text { Ankle } \\
\text { exten- } \\
\text { sion. } \\
\text { Ankle } \\
\text { abduc- } \\
\text { tion and } \\
\text { adduc- } \\
\text { tion. } \\
\text { with hip } \\
\text { rotation } \\
\text { Knee } \\
\text { flexion } \\
\text { Hip ab- } \\
\text { duction }\end{array}$ & $\begin{array}{l}\text { Knee } \\
\text { flexion/ } \\
\text { exten- } \\
\text { sion } \\
\text { Hip } \\
\text { flexion } \\
\text { Hip flex- } \\
\text { ion and } \\
\text { abduc- } \\
\text { tion } \\
\text { Plantar } \\
\text { flexion }\end{array}$ & $\begin{array}{l}\text { Ankle } \\
\text { exten- } \\
\text { sion. } \\
\text { Ankle } \\
\text { abduc- } \\
\text { tion and } \\
\text { adduc- } \\
\text { tion. } \\
\text { with hip } \\
\text { rotation } \\
\text { Knee } \\
\text { flexion } \\
\text { Hip ab- } \\
\text { duction }\end{array}$ \\
\hline $\begin{array}{l}\text { Calm } \\
\text { down }\end{array}$ & \multicolumn{12}{|c|}{$\begin{array}{l}\text { Hip abduction without TheraBands }{ }^{\circledR} \text {, both legs simultaneously. } \\
\text { Foot crossing. }\end{array}$} \\
\hline
\end{tabular}

Notes. Reps: repetitions; s: seconds;

score obtained, the higher the autonomy ${ }^{10}$. The five times sit-to-stand test is a part of the short physical performance battery and aims to assess the lower limb muscle strength/velocity ${ }^{11}$. In this test, participants are asked to stand up from a chair five times as quickly as possible and the time to complete the task, in seconds, is recorded as their performance.

Dynamic balance assessment included, the timed up and go test with wiva ${ }^{\circledR}$ sensors ${ }^{12}$. Wiva ${ }^{\circledR}$ sensors include an accelerometer, a magnetometer and a gyroscope that allow professionals and practitioners to record information about the angular velocities reached during TUG, with the inertial detection devices placed in the L4-L5 spinal segment. In addition, wiva ${ }^{\circledR}$ gathers split time data into the early stages of TUG (sit to stand, gait to go, turning, gait return, stand to sit) and the total time required to complete the task. All this information was saved and sent to a computer via Bluetooth with Biomech study 2011 v.1.1.

The sample size was calculated based on the results obtained by Hirsch et al. ${ }^{13}$ in the balance parameters (20\% differences between the groups analyzed). The comparison of two means was considered, with a level of security/confidence of $85 \%(1-\alpha)$, a statistical power of $60 \%$, and a proportion of expected losses of $20 \%$. With these criteria, the sample size should include a total of 26 subjects.

\section{STATISTICAL ANALYSIS}

All statistical analyses were completed using SPSS for Windows (IBM-SPSS, version 20.0; SPSS Inc, Chicago, Ill, USA). Summary data are presented as mean (SD) and \%. Data were checked for normality of distribution using the Kolmogorov-Smirnov test ( $>0.05)$. The groups' homogeneity was assessed using the unpaired t-test. The intervention program effects on the SG in comparison to the CG was assessed by using the ANOVA 2x2. The correlation analysis was performed to determine which stages of the TUG (sit to stand, gait to go, turning, gait return, stand to sit) may have influenced the final score (time to perform the TUG). P-values $<0.05$ (2-tailed) were considered statistically significant.

\section{RESULTS}

Twenty-six women, aged 85 years and more, following the defined inclusion criteria, were included in the study. They were randomly allocated to two groups, SG ( $n=13)$ and CG $(n=13)$. The randomization process was carried out using the statistical program SPSS for Windows in the section selecting cases/random sample of cases.

Two participants did not complete the study be- 
TABLE 2. SAMPLE CHARACTERISTICS ACCORDING TO THE LEVEL OF PHYSICAL ACTIVITY

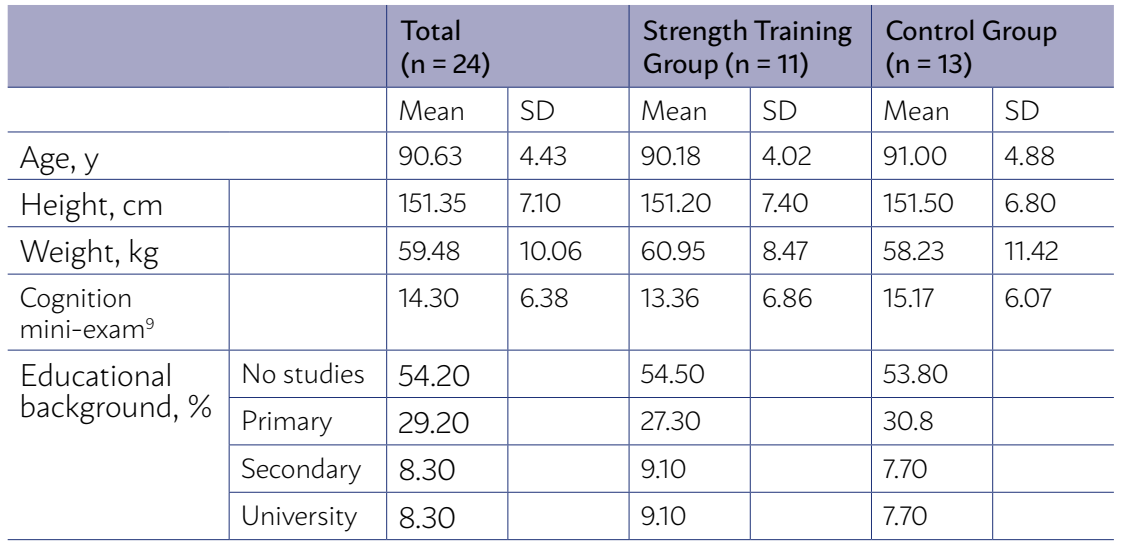

FIGURE 1. CORRELATION BETWEEN TIMED UP AND GO AND SIT TO STAND

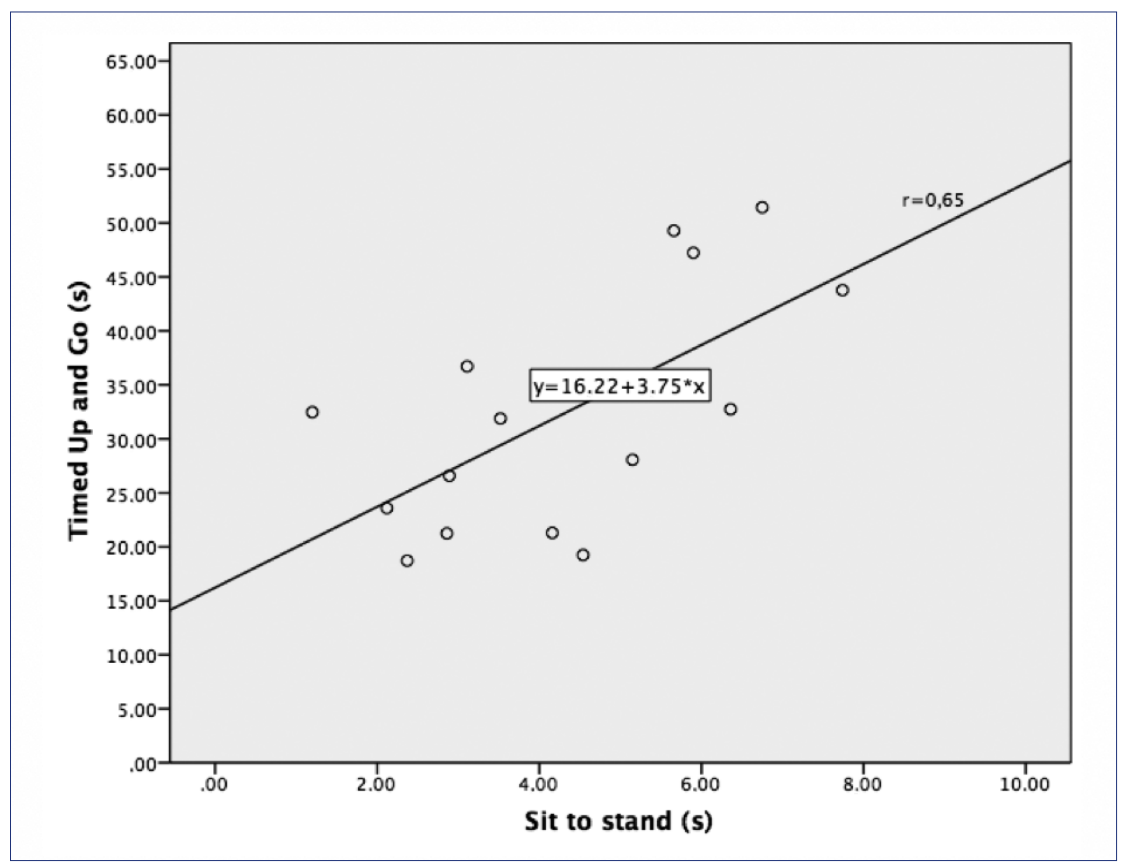

cause of death. The final number of participants was 24 (ST=11 and $\mathrm{CG}=13)$, and the average age was $90.63 \pm 4.43$ years. The detailed sample characteristics are presented in Table 2.

Table 3 indicates the statistical analysis results of the variables assessed, per group, pre- and post-intervention. Concerning the BMI, we found there was a significant improvement in the SG and significant differences between the groups post-intervention. The functional assessment showed significantly different behaviors between the groups. The SG maintained the scores on the Barthel index of activities of daily living and improved in the FTSTS; the CG showed a significant decrease on both tests. The dynamic balance test showed significant differences between the groups for the variables sit to stand, peak angular velocity, anteroposterior range, turning, stand to sit, total time, and speed. The changes within the group showed a significant decrease in sit to stand, peak angular velocity, anteroposterior range, turning, stand to sit total time, and speed, in the CG. In the SG, a significant decrease in turning was observed (Figure 1).

\section{DISCUSSION}

The present research examined the effects of a muscle strength training program through the use of TheraBands ${ }^{\circledR}$, on frail nonagenarian women. The findings show that the intervention program promoted significant improvements in function, BMI, and a trend to improve the dynamic balance parameters.

Previous studies have found significant correla- 
TABLE 3. ANALYSIS OF FUNCTIONAL PARAMETERS ACCORDING TO THE GROUP.

\begin{tabular}{|c|c|c|c|c|c|c|c|c|}
\hline & \multicolumn{4}{|c|}{$\begin{array}{l}\text { Strength Training } \\
\text { Group }(n=11)\end{array}$} & \multicolumn{4}{|c|}{$\begin{array}{l}\text { Control } \\
\text { Group }(n=13)\end{array}$} \\
\hline & \multicolumn{2}{|c|}{ Pre-test } & \multicolumn{2}{|c|}{ Post-test } & \multicolumn{2}{|c|}{ Pre-test } & \multicolumn{2}{|c|}{ Post-test } \\
\hline & Mean & SD & Mean & SD & Mean & SD & Mean & SD \\
\hline $\mathrm{BMI}, \mathrm{kg} / \mathrm{m}^{2}$ & 30.82 & 2.93 & 27.18 & $4.25^{\star}$ & 30.66 & 2.31 & 30.60 & $5.20^{\$}$ \\
\hline FTSTS, s & 16.53 & 4.86 & 12.74 & $3.12^{\star *}$ & 16.17 & 3.77 & 17.70 & $4.88^{* \$}$ \\
\hline Barthel Index & 65.91 & 24.68 & 66.87 & 25.34 & 66.92 & 20.67 & 51.67 & $21.65^{\star \$}$ \\
\hline \multicolumn{9}{|l|}{ Dynamic balance } \\
\hline \multicolumn{9}{|l|}{ TUG: Sit to Stand } \\
\hline Sit to stand, s & 4.40 & 2.43 & 4.58 & 3.02 & 4.22 & 1.66 & 6.16 & $8.67^{\star \$}$ \\
\hline $\begin{array}{l}\text { Peak Angular } \\
\text { Velocity, \% /s }\end{array}$ & 9.60 & 2.94 & 9.24 & 4.62 & 8.77 & 3.25 & 5.71 & $3.64^{* \$}$ \\
\hline AP Range, $\mathrm{m} / \mathrm{s}^{2}$ & 5.08 & 1.93 & 5.72 & 2.06 & 5.42 & 1.90 & 4.19 & $2.04^{\star \$}$ \\
\hline PD Range, $\mathrm{m} / \mathrm{s}^{2}$ & 1.73 & 0.80 & 2.64 & 1.37 & 2.69 & 0.75 & 2.29 & 0.99 \\
\hline ML Range, $\mathrm{m} / \mathrm{s}^{2}$ & 2.43 & 1.26 & 2.66 & 1.31 & 2.19 & 0.29 & 1.48 & 0.69 \\
\hline \multicolumn{9}{|l|}{ TUG: Go } \\
\hline Gait go, s & 8.05 & 3.56 & 7.53 & 6.12 & 9.06 & 4.65 & 9.87 & 4.78 \\
\hline \multicolumn{9}{|l|}{ TUG: Turning } \\
\hline Turning, s & 4.58 & 2.22 & 5.45 & $3.29^{*}$ & 7.66 & 4.42 & 8.09 & $5.28^{\$}$ \\
\hline \multicolumn{9}{|l|}{ TUG: Return } \\
\hline Gait return, s & 7.98 & 3.10 & 7.01 & 2.54 & 9.82 & 4.86 & 9.53 & 0.78 \\
\hline \multicolumn{9}{|l|}{ TUG: Stand to Sit } \\
\hline Stand to sit, s & 3.04 & 2.60 & 3.16 & 1.94 & 4.36 & 1.28 & 4.97 & $0.75^{\star \$}$ \\
\hline $\begin{array}{l}\text { Peak Angular } \\
\text { Velocity, \%/s }\end{array}$ & 129.42 & 124.12 & 127.03 & 76.34 & 99.98 & 42.13 & 98.00 & 39.15 \\
\hline \multicolumn{9}{|l|}{ TUG: total } \\
\hline Total Time, s & 28.05 & 9.99 & 27.73 & 11.62 & 35.12 & 11.59 & 38.62 & $15.44^{* \$}$ \\
\hline Speed, m/s & 0.21 & 0.08 & 0.22 & 0.09 & 0.17 & 0.06 & 0.15 & $0.06^{\star \$}$ \\
\hline
\end{tabular}

${ }^{\star} p<0.05,{ }^{\star \star} p<0.005$ significant differences intra-group, $\$ p<0.05, \$ \$ p<0.005$ significant differences inter-group. Notes. BMI: Body mass index; FTSTS: Five times sit to stand test; TUG: Timed up and go; AP: Anteroposterior; PD: Proximal distal; ML: Medium lateral.

tions between overweight and decreases in mortality in nonagenarians ${ }^{\mathbf{1 4 , 1 5}}$. In the present study, the SG showed a significant decrease in BMI, which was significantly different from the CG after the intervention program. Furthermore, the SG was classified as obesity grade I at week 0 , and overweight by week 12 , while the CG maintained obesity grade I throughout the training program. This finding may support the benefits of muscle strength intervention programs on such populations. However, more research is needed to confirm and understand the mechanisms to improve the health and quality of life.

The intervention program also improved function in nonagenarians, as shown by the FTSTS and Barthel index of activities of daily living scores. The present results are in line with previous research in which muscle strength training promoted hypertrophy, decreased fat mass, decreased falls, and increased functional capacity in such populations ${ }^{7,16}$.
The TUG test is an important tool to assess mobility and risk of falls. Aged populations completing the TUG test under 20 seconds have shown autonomy in daily living tasks, presented high scores on the Berg balance scale and can walk at optimal speed (0.5 $\mathrm{m} / \mathrm{s})^{17}$. The present findings showed that SG trend to increase their walking speed, while the CG experienced significant decreases in sit to stand, turning, and stand to sit.

There are some methodological limitations that should be considered when interpreting the results. First, the size of the sample on which the intervention was performed is small. Another limitation lies in the fact that the option of carrying out an intervention of a longer duration should be considered to see if these factors would lead to different results than those obtained. Finally, the use of novel tools, such as wiva ${ }^{\circledR}$ sensors, could be considered a limitation, as the results cannot be compared with those of other studies. 


\section{CONCLUSION}

Little research has been developed on nonagenarians. However, it seems that muscle strength intervention programs may help promote healthy lifestyles on such population by maintaining autonomy, improving function and balance.

\section{ACKNOWLEDGMENTS}

The authors would like to thank the San Rosendo Association for their participation in the study.

\section{Conflicts of interest}

The authors declare no conflicts of interest.

\section{RESUMO}

OBJETIVO: O objetivo do estudo é melhorar a capacidade funcional e a qualidade de vida (QV) de nonagenários por meio da implementação de um programa de treinamento aeróbico e de força individualizado em um centro geriátrico residencial.

DESENHO DO ESTUDO: Estudo controlado randomizado.

METODOLOGIA: Vinte e seis mulheres idosas foram randomizadas em grupo controle (CG) e grupo intervenção (SG). O SG realizou um programa de força com 12 semanas de duração de duas sessões semanais. As ferramentas de avaliação usadas antes e após a intervenção foram o Índice de Barthel das atividades da vida diária, o teste Five-to-Stand (FTSTS) e o Timed Up and Go (TUG) com sensores Wiva ${ }^{\circledR}$.

RESULTADOS: O SG manteve as pontuações no Índice de Barthel e melhora no FTSTS; o GC apresentou redução significativa nos dois testes. O teste de equilíbrio dinâmico mostrou diferenças significativas entre os grupos para as variáveis: Sit to Stand, pico da velocidade angular, amplitude anteroposterior, giro, posição sentada, tempo total e velocidade.

CONCLUSÕES: Os programas de intervenção de força muscular podem ajudar a promover estilos de vida saudáveis nesta população para a manutenção da autonomia, a melhora da função e o equilíbrio.

PalaVRas chave: Terapia por Exercício. Exercício. Fragilidade. Equilíbrio Postural. Qualidade de Vida. Idoso.

\section{REFERENCES}

1. Serra Rexach $\mid A$, Ruiz |R, Bustamante-Ara N, Villarán $M H$, Gil PG, Sanz lbáñez MJ, et al. Health enhancing strength training in nonagenarians (STRONG): rationale, design and methods. BMC Public Health. 2009;9:152.

2. Walston J, Fried LP. Frailty and the older man. Med Clin North Am 1999;83(5):1173-94.

3. Rockwood K, Mitnitski A. Frailty in relation to the accumulation of deficits. | Gerontol A Biol Sci Med Sci. 2007;62(7):722-7.

4. Rodríguez-Mañas L, Féart C, Mann G, Viña I, Chatterji S, Chodzko-Zajko W, et al; FOD-CC group. Searching for an operational definition of frailty: a Delphi method based consensus statement: the frailty operative definition-consensus conference project. | Gerontol A Biol Sci Med Sci. 2013;68(1):62-7.

5. Visser M, Goodpaster BH, Kritchevsky SB, Newman AB, Nevitt M, Rubin $S M$, et al. Muscle mass, muscle strength, and muscle fat infiltration as predictors of incident mobility limitations in well-functioning older persons. Gerontol A Biol Sci Med Sci. 2005;60(3):324-33.

6. Fried LP, Tangen CM, Walston J, Newman AB, Hirsch C, Gottdiener J, et al; Cardiovascular Health Study Collaborative Research Group. Frailty in older adults: evidence for a phenotype. I Gerontol A Biol Sci Med Sci. 2001;56(3):M146-56

7. Cadore EL, Casas-Herrero A, Zambom-Ferraresi F, Idoate F, Millor N, Gómez $M$, et al. Multicomponent exercises including muscle power training enhance muscle mass, power output, and functional outcomes in institutionalized frail nonagenarians. Age (Dordr). 2014;36(2):773-85.

8. Frisard MI, Fabre IM, Russell DR, King CM, DeLany IP, Wood RH, et al.; Louisiana Healthy Aging Study. Physical activity level and physical functionality in nonagenarians compared to individuals aged 60-74 years. I Gerontol A Biol Sci Med Sci. 2007;62(7):783-8.

9. Lobo A, Saz P, Marcos G, Día |L, de la Cámara C, Ventura T, et al. Re- validation and standardization of the cognition mini-exam (first Spanish version of the Mini-Mental Status Examination) in the general geriatric population. Med Clin (Barc). 1999;112(20):767-74

10. Mahoney FI, Barthel DW. Functional evaluation: the Barthel index. Md State Med J. 1965;61-5.

11. Guralnik JM, Ferrucci L, Pieper CF, Leveille SG, Markides KS, Ostir GV, et al. Lower extremity function and subsequent disability: consistency across studies, predictive models, and value of gait speed alone compared with the short physical performance battery. J Gerontol A Biol Sci Med Sci. 2000;55(4):M221-31.

12. Cancela Carral IM, Pallin E, Orbegozo A, Ayán Pérez C. Effects of three different chair-based exercise programs on people older than 80 years. Rejuvenation Res. 2017;20(5):411-9.

13. Hirsch MA, Toole T, Maitland CG, Rider RA. The effects of balance training and high-intensity resistance training on persons with idiopathic Parkinson's disease. Arch Phys Med Rehabil. 2003;84(8):1109-17.

14. Lisko I, Tiainen $K$, Stenholm S, Luukkaala T, Hervonen A, Jylhä M. Body mass index, waist circumference, and waist-to-hip ratio as predictors of mortality in nonagenarians: the Vitality 90+ Study. J Gerontol A Biol Sci Med Sci. 2011;66(11):1244-50.

15. Ravaglia G, Morini P, Forti P, Maioli F, Boschi F, Bernardi M, et al. Anthropometric characteristics of healthy Italian nonagenarians and centenarians. Br | Nutr. 1997;77(1):9-17.

16. Freiberger E, Häberle L, Spirduso WW, Zijlstra GA. Long-term effects of three multicomponent exercise interventions on physical performance and fall-related psychological outcomes in community-dwelling older adults: a randomized controlled trial. J Am Geriatr Soc. 2012;60(3):43746.

17. Podsiadlo D, Richardson S. The timed "Up \& Go": a test of basic functional mobility for frail elderly persons. I Am Geriat Soc. 1991;39(2):142-8. 